\title{
SPEARHEADS FROM BURIALS OF SAVROMATO-SARMATIAN TIME FROM THE TERRITORY OF VOLGOGRAD REGION (MATERIALS FOR CATALOGUE) ${ }^{1}$
}

\author{
Vladimir I. Moiseev \\ Volgograd State University, Volgograd, Russian Federation \\ Igor A. Budaev \\ Volgograd State University, Volgograd, Russian Federation
}

\begin{abstract}
Introduction. Information about the armament and military arts of nomads of the Early Iron age can be obtained from writings of Greek and Roman authors, who note the warlike temper of Savromatian and Sarmatian tribes. They mention bows, swords and spears among the armament of nomads in their works. This information is confirmed by the archaeological material. Finds of spearheads in burials are quite rare and are ranked third after arrows and swords in percentage. Methods. The typological features of spearheads are based on the shape of their pen, which allows distinguishing two types of spears - leaf-shaped and lence-shaped. Analysis. This article is the beginning of the catalog of spearheads, darts and spear counter-weights found in the Lower Volga Region in Savromatian and Sarmatian monuments. At this moment, the authors have taken into account a sample of 29 spearheads, 3 darts and 3 spear counter-weights and made their typological analysis. Results. The typological analysis, which forms the basis of our classification of spearheads, allows tracing the development of this type of armament in Volgograd region. The further development of this topic will help to find typological interrelationships of spearheads, to clarify their chronological positions and features of mutual occurrence in burials with other types of armament and equipment. In turn, this analysis will help to determine the social status of the buried persons and their role in ethnopolitical processes.

Key words: weapons, spearheads, darts, Volgograd region, Savromatian culture, Early Sarmatian culture, Middle Sarmatian culture, Late Sarmatian culture.

Citation. Moiseev V.I., Budaev I.A. Spearheads from Burials of Savromato-Sarmatian Time from the Territory of Volgograd Region (Materials for Catalogue). Vestnik Volgogradskogo gosudarstvennogo universiteta. Seriya 4. Istoriya. Regionovedenie. Mezhdunarodnye otnosheniya [Science Journal of Volgograd State University. History. Area Studies. International Relations], 2019, vol. 24, no. 5, pp. 34-50. (in Russian). DOI: https://doi.org/10.15688/ jvolsu4.2019.5.3
\end{abstract}

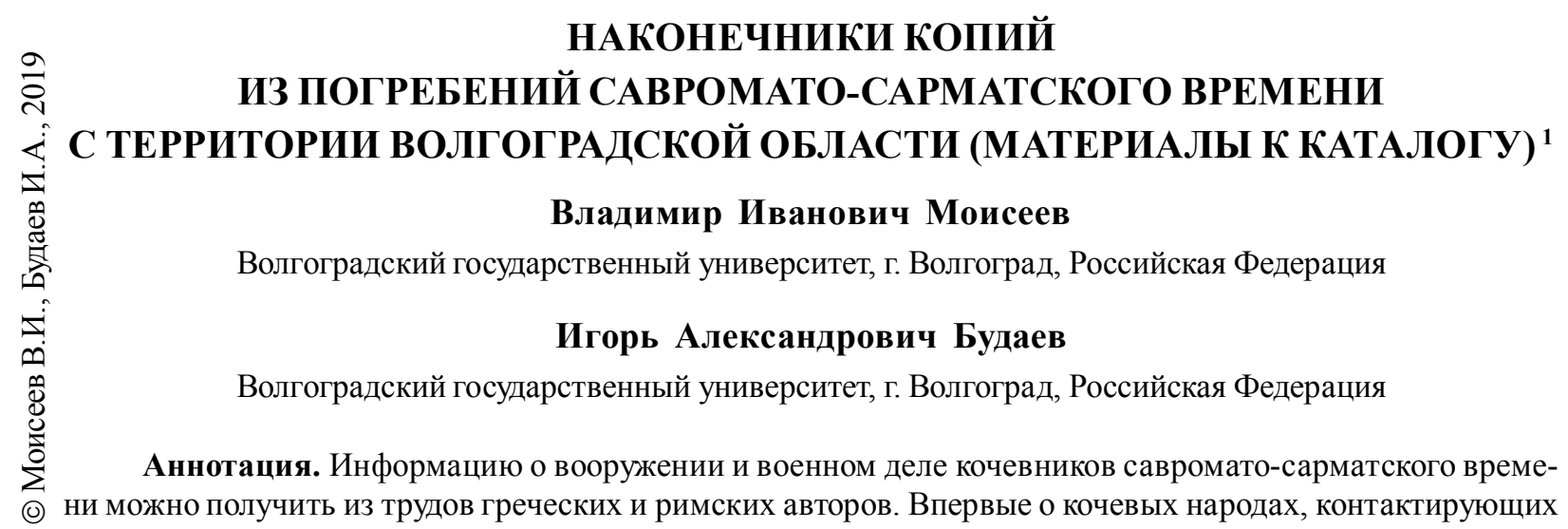


с античным миром, повествует Геродот, который один из первых подчеркивает их воинственность. Воинственный нрав савроматских и сарматских племен отмечают и другие древние писатели. В их трудах среди вооружения кочевников упоминаются луки, мечи и копья. Данные сведения находят подтверждение и в археологическом материале. Находки наконечников копий в погребениях довольно редки и в процентном отношении находятся на третьем месте после стрел и мечей. Незначительный процент наконечников копий многие исследователи объясняют, прежде всего, не особенностью погребального ритуала, а реальным составом воинов, которые имели копье в арсенале своего вооружения. Вероятнее всего, наличие последнего было признаком высокого социального статуса. Данная статья позиционируется как начало составления каталога найденных на территории Нижнего Поволжья в савроматских и сарматских памятниках наконечников копий, дротиков и втоков. В настоящий момент авторами учтена выборка из 29 наконечников копий, 3 дротиков и 3 втоков. Цель данной работы - сбор информации о данной категории вооружения и создание единой базы сведений об уже опубликованных и еще не изданных наконечниках копий и дротиков Нижнего Поволжья, что в дальнейшем позволит определить социальный статус погребенных с данным вооружением на различных этапах савромато-сарматской эпохи и установить роль этих страт в этнополитических процессах, происходящих со второй половины VI в. до н. э. (становление савроматской археологической культуры в Нижнем Поволжье) до IV в. н. э. (завершение позднесарматской культуры). И.А. Будаев в данной работе отвечал за сбор археологического материала и его прорисовку. В.И. Моисеевым проанализированы письменные источники, сделан историографический обзор исследуемой проблемы и произведен типологический анализ материала.

Ключевые слова: вооружение, наконечники копий, дротики, Волгоградская область, савроматская культура, раннесарматская культура, среднесарматская культура, позднесарматская культура.

Цитирование. Моисеев В. И., Будаев И. А. Наконечники копий из погребений савромато-сарматского времени с территории Волгоградской области (материалы к каталогу) // Вестник Волгоградского государственного университета. Серия 4, История. Регионоведение. Международные отношения. - 2019. - Т. 24 , № 5. - C. 34-50. - DOI: https://doi.org/10.15688/jvolsu4.2019.5.3

Введение. Античные авторы сообщают о воинственности савромато-сарматских племен, в ряде случаев они приводят сведения о типах оружия, используемых ими, среди которых упоминаются копья. Сведения из письменных источников подтверждаются находками копий, дротиков и втоков от них в погребениях кочевников скифо-сарматского времени, обитавших на территории Нижнего Поволжья.

Работ савромато-сарматского времени, посвященных копьям, немного, что можно объяснить сравнительно небольшим процентом их встречаемости в погребениях. Исследователи в рамках своих работ, посвященных военному делу кочевников раннего железного века, периодически приводят общие сведения по данному виду оружия.

К.Ф. Смирнов отмечал, что наконечники копий сравнительно редко находят в савроматских погребениях и в процентном отношении они занимают третье место после лука со стрелами и мечей. Данная ситуация, по его мнению, объясняется не особенностью погребального обряда, а реальным составом воинов ранних кочевников Поволжья и Южного Приуралья [34, с. 70-71].
Схожего мнения придерживается П.М. Соколов, отмечая, что копья были принадлежностью элиты и в могилах они являлись маркером социального статуса погребенного [35, с. 68-72].

A.M. Хазанова замечает, что копья у савроматских племен (в сравнении со скифской культурой) имеют незначительное распространение. Исследователь объясняет это появлением длинных всаднических мечей, которые могли заменять копья. С его точки зрения, военное дело савроматов основывалось на тех же принципах, которые в более развитом виде проявились в следующие века. Освоение новых тактических приемов в военном деле произошло у сарматов во время развитой прохоровской культуры. Однако и для этого времени, как отмечает А.М. Хазанов, скорее всего, копья были на вооружении у определенных элитных воинских групп [36, с. 45].

В.Н. Васильев, оперируя археологическими материалами Южного Приуралья, также отмечает появление большого числа копий в прохоровское время. Он считает, что начало рассматриваемого процесса в военном деле на территории данного региона приходится на период V-IV вв. до н. э. [4, с. 71]. 


\section{АРХЕОЛОГИЯ ВОСТОЧНО-ЕВРОПЕЙСКИХ СТЕПЕЙ}

В IV в. до н. э. в результате военной экспансии южноуральские кочевники осваивают огромную степную территорию к западу от Приуралья [32, с. 19]. На территории Нижнего Поволжья в это время увеличивается количество копий. Большинство из них найдены в погребениях с явными южноуральскими признаками (диагональные погребения и погребения в дромосных ямах, глиняная посуда с тальком в тесте, мечи так называемого переходного типа с дуговидным или изогнутым под тупым углом перекрестием).

В сусловскую эпоху, по мнению А.М. Хазанова, копья были постоянным оружием сарматов. В дальнейшем они становятся основным наступательным оружием катафрактариев [36, с. 45].

О кардинальных изменениях в вооружении и в тактике боя в среднесарматское время упоминает и В.П. Глебов. По материалам Нижнего Подонья исследователь отмечает большое наличие дротиков и копий в IV - начале III в. до н. э., во II-I вв. до н. э. их количество значительно сокращается, а в среднесарматское время фиксирует возросшее количество находок наконечников в погребальных комплексах [5, с. 98].

Методы и материалы. На территории Нижнего Поволжья нами учтено 29 наконечников копий, 3 дротика и 3 втока савроматосарматского времени. Некоторые из них плохой сохранности и поэтому сложно определить их тип. Несмотря на то что учтенная нами выборка наконечников копий хронологически разновременная, все они вписываются в типологическую схему, разработанную А.И. Милюковой для скифского [22, с. $35-$ 45] и А.М. Хазановым для сарматского оружия [36, с. 46-48] и используемую большинством исследователей $[3$, с. 335-336; 4, с. 29; 10, c. $32 ; 26$, с. 70 ; и др.]. Многие из них, беря за основу классификацию А.М. Хазанова и А.И. Милюковой, варьируют ее в зависимости от вновь появившихся наконечников копий в изучаемом регионе.

В связи с ограниченностью собранного нами материала мы не можем предложить свою типологию, поэтому наиболее корректно будет использовать типологию, предложенную А.М. Хазановым, как разработанную на одноэтничном материале по отношению к на- шей выборке и наиболее подходящую для наконечников копий с Нижневолжской территории [36, с. 46-48].

В соответствии с типологией А.М. Хазанова наконечники копий из представленной выборки можно разделить на четыре типа. Однако из-за отсутствия нумерации в этой типологии нам пришлось выделенным типам присвоить свои номера. В основу типологических признаков наконечников копий положена форма их пера, а также соотношения размеров пера и втулки.

Tun 1. Наконечники копий с массивным листовидным пером и короткой втулкой (рис. 1, 2). У данных наконечников очень короткая втулка и длинное массивное и широкое перо с ребром посередине. Длина втулки составляет примерно $1 / 5$ общей длины наконечника.

Tun 2. Наконечники копий с коротким массивным листовидным пером и длинной втулкой (рис. 1, 3-5; рис. 2, 1-15). Перо наконечника данного типа небольшое по длине, массивное, в сечении линзовидное. Размер втулки составляет около половины общей длины наконечника или даже больше. Данные экземпляры на конце втулки могут иметь валик или муфту-кольцо, которые, по мнению А.М. Хазанова, препятствовали проникновению наконечника копья глубоко в тело противника или просто упирались в древко. По длине такие наконечники варьируются довольно сильно. Происхождение их не вполне ясно, так как такие наконечники бытовали с раннего времени на Кавказе и известны у сарматов с IV в. до н. э. [36, с. 47].

Tun 3. Наконечники копий с ланцетовидным пером (рис. 3, 1, 3, 4). Перо у наконечников данного типа узкое и плоское, нижняя часть пера плавно закруглена ко втулке. Длина втулки составляет примерно от $1 / 2$ до $1 / 3$ общей длины наконечника.

Tun 4. Наконечники копий «закавказского типа». Довольно узкое (ланцетовидное) перо резко переходит во втулку под тупым или почти прямым углом [36, с. 47] (рис. 3, 6-12). Длина втулки составляет примерно от $1 / 2$ до $2 / 3$ общей длины наконечника.

Анализ. Наконечники 1-го типа (1 экз.). Наконечники таких копий в нашей выборке представлены одним экземпляром 
длиной 52 см из Калиновского могильника: кург. 55, погр. 14 (табл. 1, 2). Перо данного наконечника имеет продольные бороздки, втулку с несмыкающимися краями (рис. 1,2 ) $[37$, c. 406]. Наконечники данного типа, по мнению А.М. Хазанова [36, с. 47] и В.П. Шилова [37, с. 462], скорее всего, имеют северокавказское происхождение и датируются в пределах последних веков до н. э. - первых веков нашей эры.

Наконечники 2-го типа (16 экз.). Наконечники копий с линзовидным в сечении пером найдены в курганных могильниках Калиновка (кург. 6, погр. 5), Ежовка (кург. 3, погр. 3), Первомайский VIII (кург. 9, погр. 3), Жутово (кург. 34, погр. 4, 6), Котлубань II (кург. 2, находка в насыпи [рис. 2, 9; табл. 1, 18]) [29], Котлубань V (кург. 2, погр. 1) [12], Эльтон (кург. 10, погр. 9) [13], Ковалевка (кург. 9, погр. 1; кург. 11, погр. 1; кург. 12, погр. 2) [8], Лозной I (гр. III, кург. 2, погр. 1) [33], Могута (кург. 8, погр. 3) [30], Майеровский III (кург. 4, погр. 3А) [28, с. 98-117], Барановка I (кург. 10, погр. 1) [24]. Перо копья из погр. 3 кург. 8 могильника Могута отличалось от остальных ромбовидным сечением (рис. 2, 4; табл. 1, 9). Наконечник из могильника Лозной I (гр. III, кург. 2, погр.1) по сведениям из отчета также имел ромбическое в сечении перо, однако разрез пера на прорисовке имеет линзовидное сечение (рис. 2, 14; табл. 1, 16).

В Калиновском курганном могильнике в погр. 5 кург. 6 был найден наконечник размерами 26 см при длине втулки 12 см, наибольшая ширина пера составляет 6,6 см, диаметр втулки -6 см (табл. 1, 5). На конце втулка имеет валик (рис. 1, 4) [37, с. 342].

Длинную втулку, округлую в сечении, с валиком по краю имеет наконечник копья из погр. 3 кург. 3 могильника Ежовка (табл. 1, 4) [17]. Перо наконечника плохой сохранности, однако форму его пера можно восстановить как листовидную (рис. 1, 5).

Полностью не восстанавливается сильно коррозированный наконечник из погр. 3 кург. 9 могильника Первомайский VIII (табл. 1, 3). Реконструируемая длина наконечника равна 30 см. Перо было изогнуто по отношению ко втулке еще в древности. Длина втулки 15,5 см. На нижней части она имеет валик диаметром 5 см. Длина листовидного наконеч- ника - около 14 см, ширина - 5,8 см. Несмотря на широкую листовидную форму, в нижней части перо переходит во втулку под тупым углом, как у ланцетовидных наконечников копий закавказского типа (рис. 1, 3) [20].

Муфтообразное утолщение на конце втулки имеют еще четыре экземпляра (Майеровский III, кург. 4, погр. 3А [рис. 2, 6; табл. 1, 11]; Лозной I, гр. III, кург. 2, погр. 1 [рис. 2, 14; табл. 1, 16]; Котлубань V, кург. 2, погр. 1 [рис. 2, 10; табл. 1, 17]; Ковалевка, кург. 12, погр. 2 [рис. 2, 11; табл. 1, 14]). Втулки трех наконечников имеют несомкнутые края (Ковалевка, кург. 11, погр. 1 [рис. 2, 12; табл. 1, 13], Эльтон, кург. 10, погр. 9 [рис. 2, 5; табл. 1, 10], Ежовка, кург. 3, погр. 3 [рис. 1, 5; табл. 1, 4]).

Наконечники копий из могильников Майоровский III (кург. 4, погр. 3А [рис. 2, 6; табл. 1, 11]) и Ковалевка (кург. 9, погр. 1 [рис. 2, 7; табл. 1, 12]) имеют ребра жесткости посередине пера.

Длина наконечников варьируется от 17,2 см (Барановка I, кург. 10, погр. 1 [рис. 2, 13; табл. 1, 15]) до 49,5 см (Жутово, кург. 34, погр. 4, 6 [рис. 2, 1; табл. 1, 7]). Самые крупные экземпляры второго типа представлены в курганном могильнике Жутово (кург. 34, погр. 4, 6) [16; 9, с. 67-70]. Один из наконечников был во фрагментированном состоянии (рис. 2, 1). Реконструируемая длина составила 49,5 см. Размер сохранившейся части пера -24 см длиной и 4 см шириной. Втулка длиной 26 см, диаметр у основания пера 2,8 см, диаметр отверстия, через которое насаживалось древко, составляет 3,1 см (табл. 1,7 ). Второй железный наконечник копья (длиной 48 см) на конце втулки имел валик (рис. 2, 2). Диаметр втулки -4 см. Перо наконечника при длине 32 см имело ширину 5,4 см (рис. 1,8). К этому наконечнику относится железный вток, найденный в противоположном углу погребения (рис. 2, 3). Длина - 3,9 см, диаметр 3,2 см (табл. 2, 2). Расстояние между наконечником копья и втоком позволяет установить длину копья $-3,4$ м.

К листовидным наконечникам можно отнести фрагментированный наконечник из могильника Химкомбинат (гр. Б, кург. 4, погр. 1 [рис. 1,1 ; табл. 1, 1]) [19] и обломок пера копья из кургана 31 могильника Жутово (рис. 2, 15) [16]. Острие копья из кургана 31 облома- 


\section{АРХЕОЛОГИЯ ВОСТОЧНО-ЕВРОПЕЙСКИХ СТЕПЕЙ}

но, втулка отсутствует. Длина - 21 см, наибольшая ширина $-5,5$ см, толщина лезвия 2,8 см (табл. 1, 1). В связи с его фрагментированным состоянием типологию определить достаточно сложно, однако пропорции и внешний вид позволяют отнести его к наконечникам второго типа.

Наконечники копий второго типа встречаются во всех сарматских культурах. Одиннадцать наконечников были обнаружены в погребениях раннесармаского времени IV-I вв. до н. э. в могильниках Ежовка, Жутово, Могута, Эльтон, Майеровский III, Барановка I, Ковалевка. Наконечники, подобные образцу, найденному в погр. 1 кург. 9 могильника Ковалевка, вероятно, появляются в предскифское время. Экземпляр из погр. 11 кург. 10 могильника Барановка I датируется VIII в. до н. э. Размеры: длина -32 см, длина пера $-17,7$ см, ширина пера - 4,2 см, диаметр втулки - 3,2 см (рис. 2, 8).

Образцы из Калиновского (кург. 6, погр. 5), Первомайского VIII (кург. 9, погр. 3) и Лозного I (гр. III, кург. 2, погр. 1) могильников можно датировать I в. н. э. - первой половиной II в. н. э.

Позднесарматское время представлено одним наконечником из могильника Котлубань V (кург. 2, погр. 1).

Наконечники 3-го типа (4 экз.). Узкое, ромбовидное в сечении перо наконечника копья из погр. 2 кург. 11 могильника Солодовка I (рис. 3,1 ) имеет длину 28 см, ширину в средней части -4 см. Общая длина наконечника составила 42 см. Втулка с несмыкающимися краями диаметром 4,5 см (табл. 1, 19). Внутри втулки обнаружена усеченно-конической формы ворворка, в которую, по мнению автора отчета А.А. Глухова, упиралось древко копья. Вместе с наконечником в погребении также был найден железный вток копья (рис. 3, 2). Размеры: длина - 19,4 см, ширина - 4 см (табл. 2, 1). Он находился на одной оси с наконечником, что свидетельствует о помещении в погребение целиком всего копья [6].

К третьему типу можно отнести экземпляры из погр. 3 кург. 2 могильника Быково (рис. 3,3 ) и погр. 2 кург. 28 Калиновского могильника (рис. 3, 12). Общая длина наконечника из могильника Быково составила 44 см, узкое перо плоское, линзовидное в сечении, без ребра - длиной 29 см, в широкой части шириной 4,8 см. Втулка с валикообразным утолщением диаметром 5,4 см (табл. 1, 20) [31]. Длина наконечника копья из Калиновского могильника составляет $28,5 \mathrm{~cm}$, диаметр втулки у края 4,3 см при ширине пера 2,8 см (табл. 1,21 ) [37, c. 384].

Аналогичный железный наконечник копья ланцетовидной формы с полукруглым насадом был обнаружен в погр. 1 кург. 1 могильника Гремячий III (рис. 3, 4; табл. 1, 22). Там же был обнаружен втульчатый воронковидный насад с валиком по краю, который, расширяясь, переходит в прямоугольную зубилообразную втулку, прямоугольный в сечении (рис. 3, 5; табл. 2, 2) [7].

Представленные в нашей выборке наконечники третьего типа появляются в савроматское время (Солодовка I, кург. 11, погр. 2). В раннесарматский период они продолжают свое существование. Образец из погр. 3 кург. 2 могильника Быково датируется III-ІІ вв. до н. э. Наконечники третьего типа среднесарматского времени не нашли отражения в нашей выборке. Позднесарматский период представлен двумя экземплярами. III в. н. э. датируется наконечник копья из могильника Гремячий III, обнаруженный в погр. 1 кург. 1. Возможно, позднесарматским временем (IIIV вв. н. э.?) [1, с. 10] можно датировать образец из погр. 2 кург. 28 Калиновского могильника.

Наконечники 4-го типа (6 экз.). Наконечник копья этого типа был найден в погр. 9 кург. 5 могильника Бережновка (южная группа). Его узкое перо длиной 23 см (при общей длине наконечника 45 см) переходит во втулку под тупым углом. Диаметр втулки $-3 \mathrm{~cm}$ (рис. 3, 6; табл. 1, 23) [27, с. 114].

Наконечник закавказского типа из погр. 2 кург. 5 могильника Вертячий имеет узкое в сечении ромбовидное перо. По нему проходит неглубокий желобок (рис. 3, 8). Длина пера - 22 см, большая ширина -4 см. Втулка длиной 16,8 см, круглая в сечении, диаметром 3,2 см (табл. 1, 24) [18].

Еще один железный втульчатый наконечник копья с узким пером в виде вытянутого треугольника обнаружен в погр. 2 Журова кургана (табл. 1, 25). Ромбовидное в сечении перо резко переходит во втулку под тупым 
углом. Края втулки стянуты валикообразным утолщением (рис. 3, 7) [14, с. 160-164].

Наконечники копий закавказского типа, по мнению А.М. Хазанова, можно отнести к доскифскому времени. Они появились еще в бронзовом веке и распространяются в раннежелезном времени [36, с. 48]. Образцы, составившие нашу выборку, датируются савроматским (погр. 9 кург. 5 могильника Бережновка [юж. гр.], погр. 2 кург. 5 могильника Вертячий) и раннесарматским временем (погр. 2 Журова кургана).

Выше мы отмечали плохую сохранность в погребениях рассматриваемой категории инвентаря. Часто восстановить форму и размеры наконечников копий довольно сложно. К числу таких экземпляров относится изделие раннесарматского времени (III-II вв. до н. э.) из погр. 9 кург. 4 могильника Солодовка I (рис. 1, 9). Наконечник копья или дротика очень плохой сохранности, реконструируемая длина не менее $22 \mathrm{~cm}$, диаметр втулки около 3,5 см (табл. 1, 28) [23]. В погр. 3 кург. 3 могильника Маляевка V найдена втулка железного копья длиной 13 см (табл. 1, 27). Втулка у основания диаметром 4 см, имеет муфтообразное утолщение (рис. 1, 7) [25]. Кроме того, коррозированная втулка железного копья (рис. 1, б) сохранилась в погр. 13 кург. 4 могильника Политотдельское. Длина - 11 см, диаметр у основания $-3,5$ см. По направлению к перу втулка сужалась, диаметр сохранившейся части равен 2 см (табл. 1, 26) [11]. В могильнике Петропавловка I в насыпи кург. 2 был найден фрагмент пера наконечника копья размером 11,5 на 5,9 см (табл. 1, 29). Перо в сечении ромбовидное, посередине него проходил желобок (рис. 1, 8) [21].

Отдельной категорией вооружения кочевников, близкой к наконечникам копий, являются дротики. Данный тип оружия, довольно часто встречающийся у скифов и савроматов, редко находят в погребениях сарматского времени. Это обусловлено, видимо, тем, что в это время происходят изменения в тактике боя, переход от метания дротиков и копий на расстоянии к копейным штурмовым ударам сарматской конницы [36, с. $50 ; 29$, с. 76].

В нашей выборке 3 наконечника дротика раннесарматского времени. Два наконечника из погребения 2 Журова кургана имели схожие черты: это узкие ромбовидные в сечении перья и длинные втулки с муфтообразными утолщениями на конце. Однако перо одного из них переходит во втулку под прямым углом (рис. 3,11 ; табл. 1, 30), а у второго опущенные вниз жала (рис. 3,10 ; табл. 1, 31) [14, c. 160-164]. Жаловидный наконечник пера дротика также был обнаружен в погр. 7 кург. 2 могильника Эльтон (группа у с. Приозерное). Длинная втулка расширялась к основанию (рис. 3, 19; табл. 1, 32) [15].

Результаты. Несмотря на то что подборка наконечников копий и дротиков, приведенная нами, является только частью этого типа вооружения ранних кочевников Нижнего Поволжья, она дает некоторое представление о типологии и хронологии данного вида вооружения, используемого кочевыми племенами савромато-сарматского времени.

Типологический анализ, легший в основу нашей классификации наконечников копий, позволяет в некоторой мере проследить распределение этого вида вооружения во времени. Савроматское время в выборке представлено тремя наконечниками ланцетовидных типов. Копья данных типов продолжают свое существование у кочевников раннесарматского времени.

Больше всего наконечников копий в выборке происходят из раннесарматских погребений. К данному времени относятся наконечники листовидных (12 шт.) и ланцетовидных (5 шт.) типов. Наибольшее количество копий раннесарматского периода типологически относятся ко второму типу (11 шт.). Данному типу также принадлежат три образца наконечников из погребений среднесарматского времени. В среднесарматских комплексах не отмечены находки наконечников копий с ланцетовидной формой пера, однако в позднесарматской культуре они вновь встречаются. В погребениях позднесарматского времени найдены листовидный наконечник второго типа и два наконечника третьего типа.

Дальнейшая разработка данной темы позволит уточнить их хронологические позиции и особенности взаимовстречаемости в погребальных комплексах с другими типами вооружения и инвентарем. В свою очередь данный анализ поможет уточнить особенности организации сарматского войска в разные периоды, определить социальный статус по- 


\section{АРХЕОЛОГИЯ ВОСТОЧНО-ЕВРОПЕЙСКИХ СТЕПЕЙ}

гребенных и их роль в этнополитических процессах, происходивших на территории Нижнего Поволжья в раннем железом веке.

\section{ПРИМЕЧАНИЕ}

${ }^{1}$ Статья выполнена в рамках Государственного задания Министерства образования и науки
РФ, проект № 33.2830.2017/4.6 «Юг России в эпоху раннего железного века: диалог культур Восток Запад».

The reported article was carried out in the framework of the state task of the Ministry of Science and Higher Education of the Russian Federation, project number 33.2830.2017/4.6 "South of Russia in the Early Iron Age: Dialogue of East and West Cultures". 


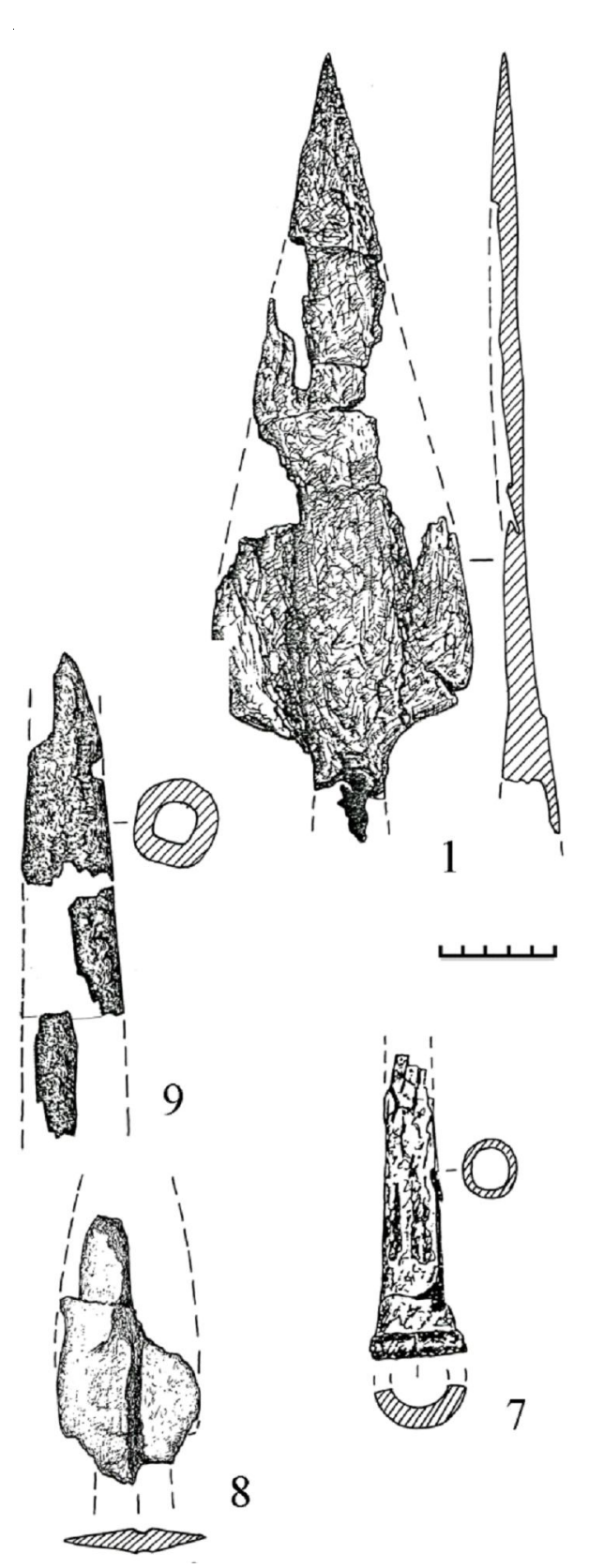

\section{ПРИЛОЖЕНИЕ}

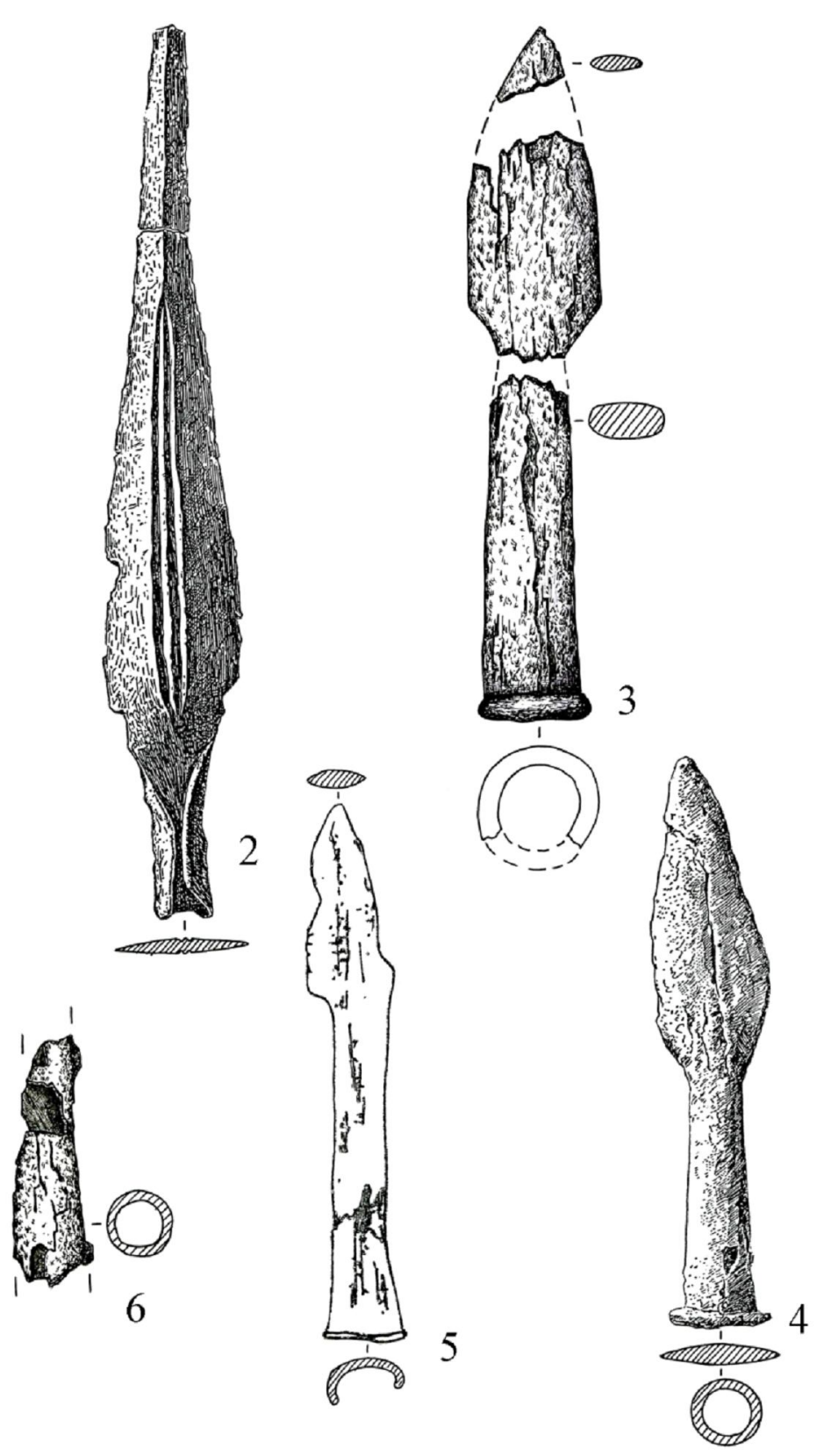

Рис. 1. Наконечники копий 1-го и 2-го типов:

1 - Химкомбинат, гр. Б, кург. 4, погр. 1; 2 - Калиновка, кург. 55, погр. 14; 3 - Первомайский VII, кург. 9, погр. 3; 4 - Калиновка, кург. 6, погр. 5; 5 - Ежовка, кург. 3, погр. 3; 6 - Политотдельское, кург. 4, погр.13;

7 - Маляевка V, кург. 3, погр. 3; 8 - Петропавловка I, кург. 2, насыпь-I H-1; 9 - Солодовка I, кург. 4, погр. 9

Fig. 1. Spearheads of types 1 and 2:

1 - Khimkombinat, group B, barrow 4, burial 1; 2 - Kalinovka, barrow 55, burial 14; 3 - Pervomayskiy VII, barrow 9, burial 3; 4 - Kalinovka, barrow 6, burial 5; 5 - Ezhovka, barrow 3, burial 3; 6 - Politotdelskoe, barrow 4, burial 13;

7 - Malyaevka V, barrow 3, burial 3; 8 - Petropavlovka I, barrow 2, mound-I, H-1; 9 - Solodovka I, barrow 4, burial 9 


\section{АРХЕОЛОГИЯ ВОСТОЧНО-ЕВРОПЕЙСКИХ СТЕПЕЙ}
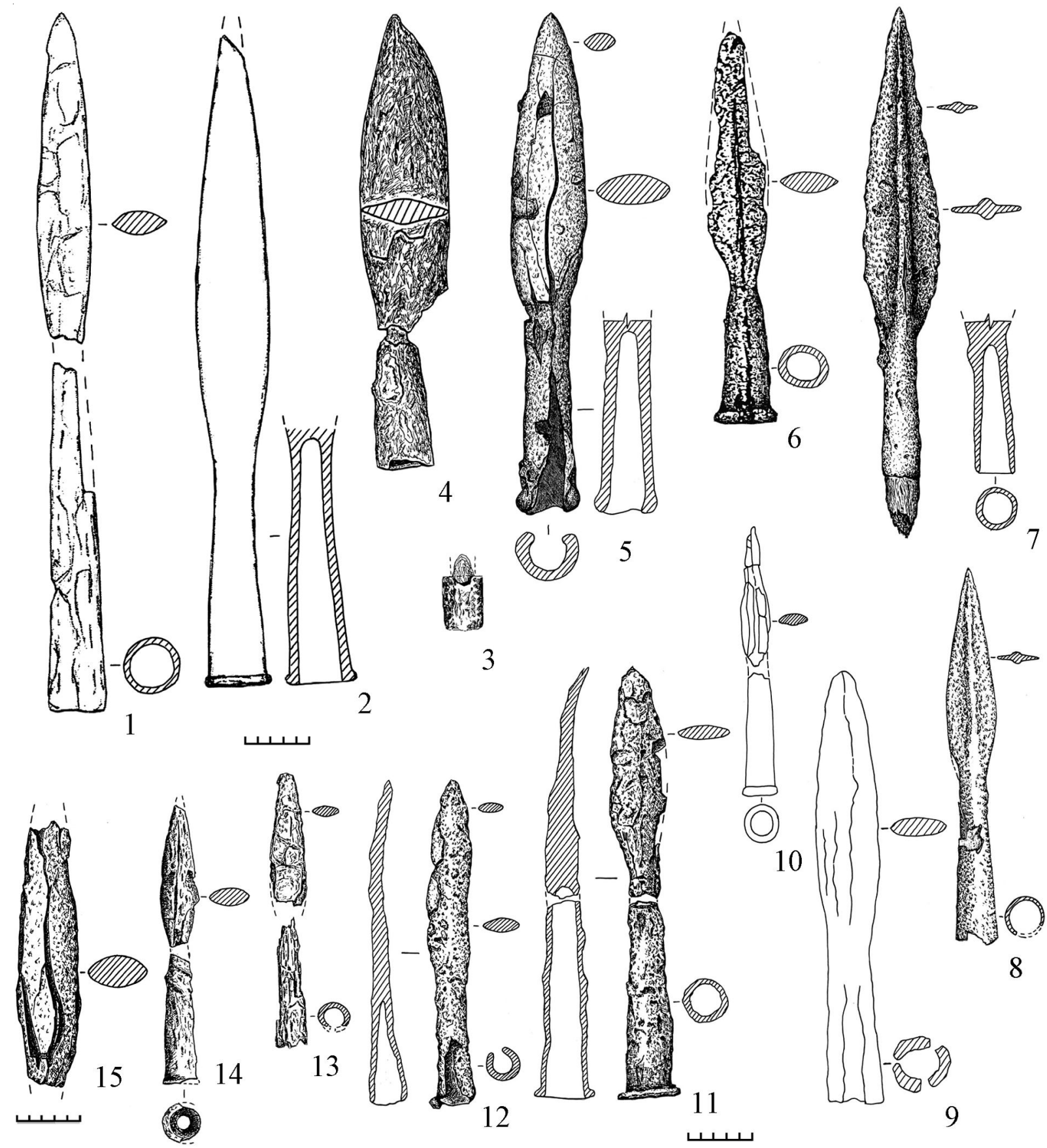

Рис. 2. Наконечники копий 2-го типа:

1-3 - Жутово, кург. 34, погр. 4, 6; 4 - Могута, кург. 8, погр. 3; 5 - Эльтон, кург. 10, погр. 9; 6 - Майеровский III, кург. 4, погр. 3А; 7 - Ковалевка, кург. 9, погр. 1; 8 - Барановка I, кург. 10, погр. 11; 9 - Котлубань II, кург. 2, находка в насыпи; 10 - Котлубань V, кург. 2, погр. 1; 11 - Ковалевка, кург. 12, погр. 2; 12 - Ковалевка, кург. 11, погр. 1; 13 - Барановка I, кург. 10, погр. 1; 14 - Лозной I, гр. III, кург. 2, погр. 1; 15 - Жутово, кург. 31, погр. 1

Fig. 2. Spearheads of type 2:

1-3 - Zhutovo, barrow 34, burial 4,6; 4 - Moguta, barrow 8, burial 3; 5 - Elton, barrow 10, burial 9; 6 - Mayerovskiy III, barrow 4, burial 3A; 7 - Kovalevka, barrow 9, burial 1;8 - Baranovka I, barrow 10, burial 11; 9 - Kotluban II, barrow 2, find in the mound; 10 - Kotluban V, barrow 2, burial 1; 11 - Kovalevka, barrow 12, burial 2; 12 - Kovalevka, barrow 11, burial 1; 13 - Baranovka I, barrow 10, burial 1; 14 - Loznoy I, group III, barrow 2, burial 1; 15 - Zhutovo, barrow 31, burial 1 

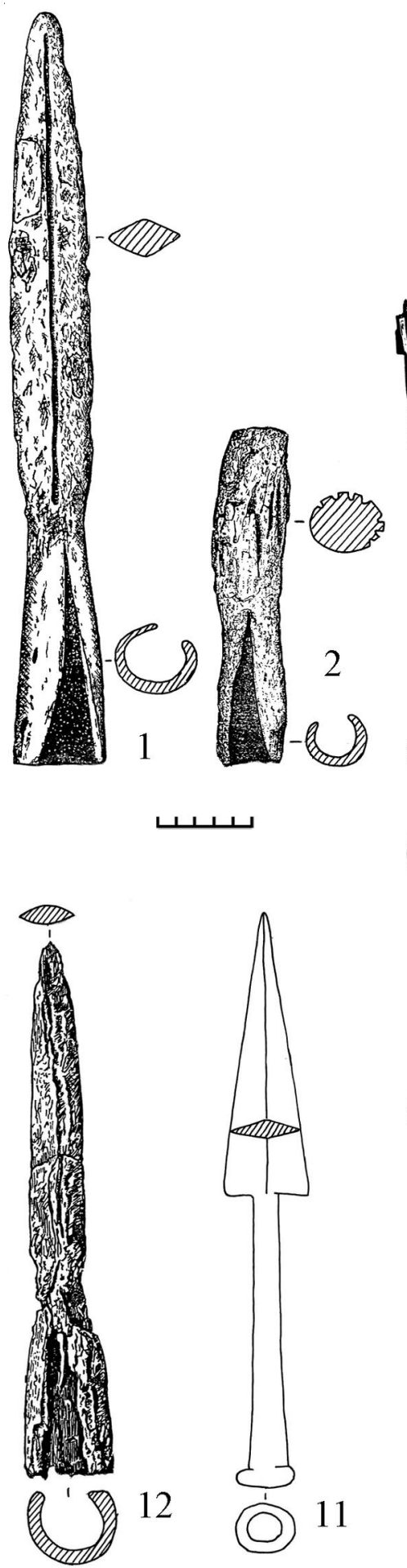
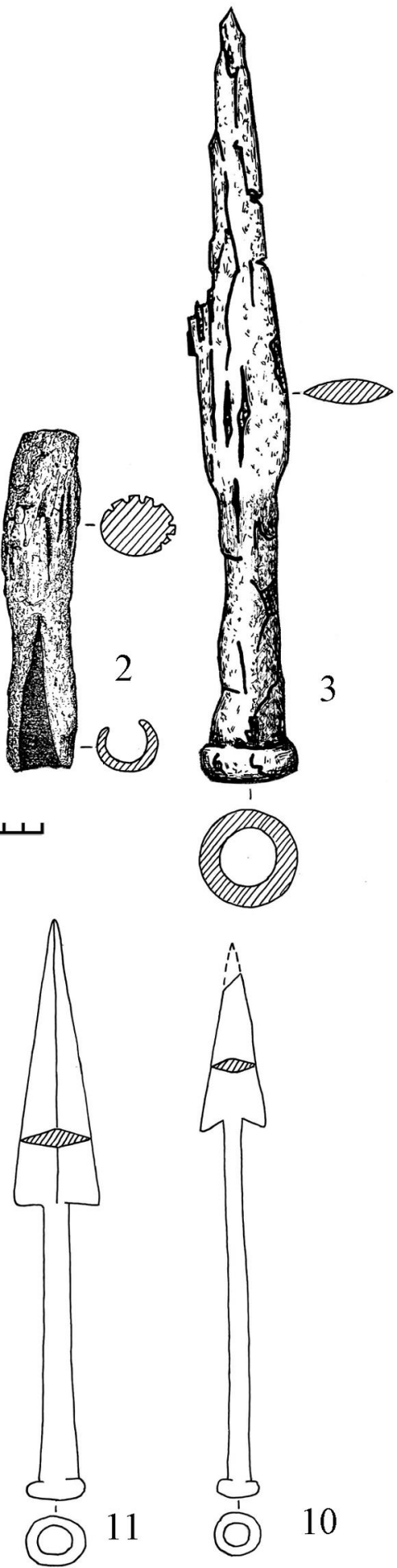
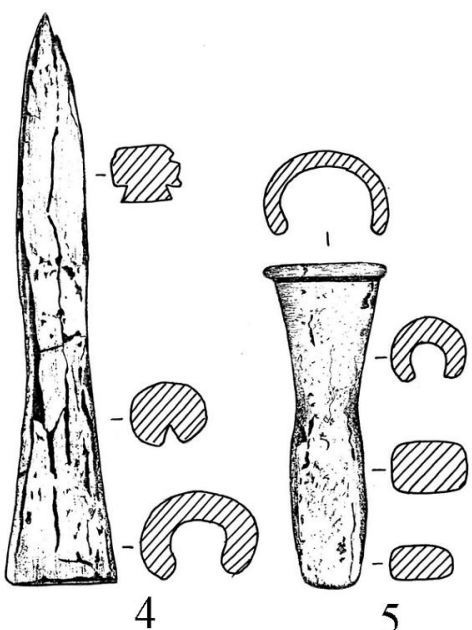

5
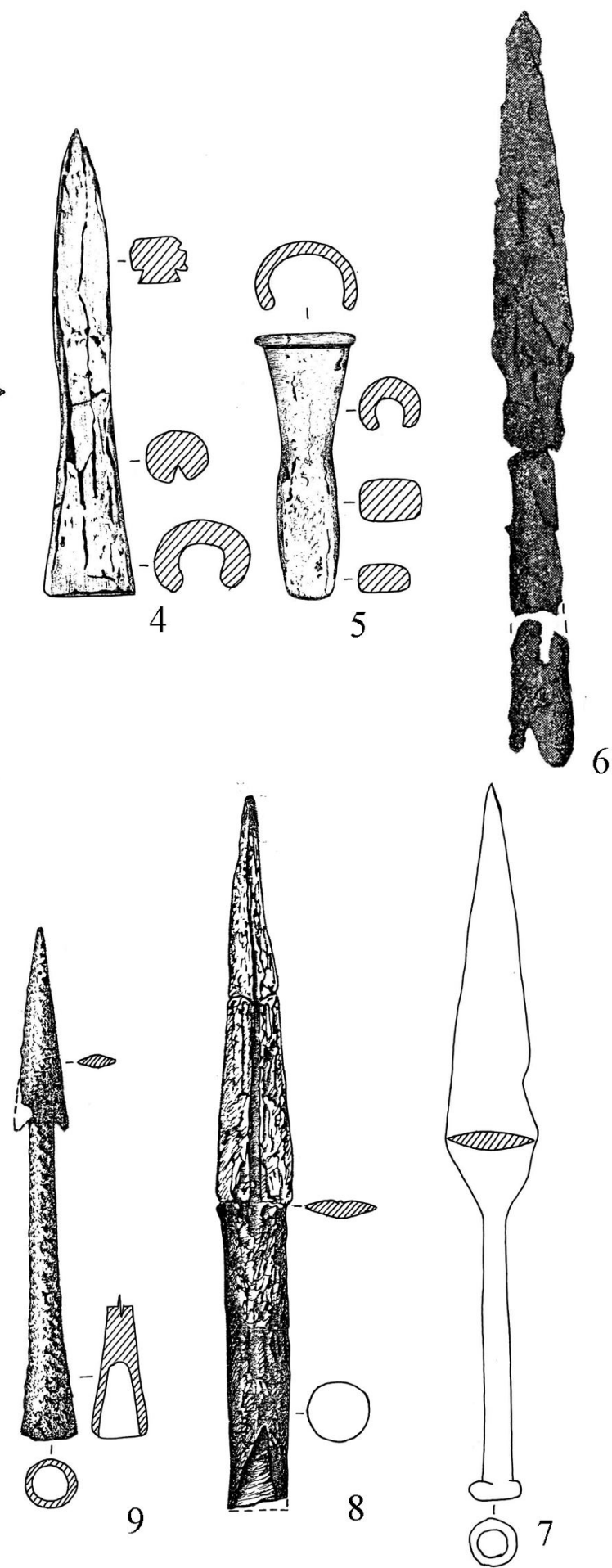

Рис. 3. Наконечники копий и дротиков 3-го и 4-го типов:

1-2 - Солодовка I, кург. 11, погр. 2; 3 - Быково, кург. 2, погр. 3; 4-5 - Гремячий III, кург. 1, погр. 1; 6 - Бережновка (юж. гр.), кург. 5, погр. 9; 7, 10, 11 - Журов курган, погр. 2; 8 - Вертячий, кург. 5, погр. 2; 9 - Эльтон (гр. у с. Приозерное), кург. 2, погр. 7; 12 - Калиновка, кург. 28, погр. 2

Fig. 3. Spearheads and darts of types 3 and 4 :

1-2 - Solodovka I, barrow 11, burial 2; 3 - Bykovo, barrow 2, burial 3; 4-5 - Gremyachiy III, barrow 1, burial 1; 6 - Berezhnovka (southern group), barrow 5, burial 9; 7, 10, 11 - Zhurov barrow, burial 2; 8 - Vertyachiy, barrow 5, burial 2; 9 - Elton (group near Priozernoe settlement), barrow 2, burial 7; 12 - Kalinovka, barrow 28, burial 2 


\section{АРХЕОЛОГИЯ ВОСТОЧНО-ЕВРОПЕЙСКИХ СТЕПЕЙ}

Таблица 1. Наконечники копий и дротиков из погребений савромато-сарматского времени с территории Волгоградской области

Table 1. Spearheads and darts from burials of the Savromato-Sarmatian period from the territory of Volgograd region

\begin{tabular}{|c|c|c|c|c|c|c|c|c|}
\hline № & Памятник & $\begin{array}{c}\text { Общая } \\
\text { длина, см }\end{array}$ & $\begin{array}{c}\text { Длина } \\
\text { пера, см }\end{array}$ & $\begin{array}{l}\text { Ширина } \\
\text { пера, см }\end{array}$ & $\begin{array}{c}\text { Диаметр } \\
\text { втулки, см } \\
\end{array}$ & Дата комплекса & Тип & Источник \\
\hline \multicolumn{9}{|c|}{ Наконечники копий } \\
\hline 1 & $\begin{array}{l}\text { Химкомбинат, гр. Б, } \\
\text { кург. } 4 \text {, погр. } 1 \\
\text { (рис. } 1,1)\end{array}$ & coxp. 35 & 30 & 10,4 & - & сарматское время & (?) & [19] \\
\hline 2 & $\begin{array}{l}\text { Калиновка, кург. 55, } \\
\text { погр. } 14 \text { (рис. } 1,2)\end{array}$ & 52 & 44 & 6 & 2,6 & $\begin{array}{l}\text { раннесарматское } \\
\text { время (I в. до н. э.) }\end{array}$ & 1 & {$[37$, c. 406$]$} \\
\hline 3 & $\begin{array}{l}\text { Первомайский VII, } \\
\text { кург. 9, погр. } 3 \\
\text { (рис. } 1,3 \text { ) }\end{array}$ & ок. 30 & coxp. 14 & 5,8 & 5 & $\begin{array}{l}\text { среднесарматское } \\
\text { время }\end{array}$ & 2 & [20] \\
\hline 4 & $\begin{array}{l}\text { Ежовка, кург. 3, } \\
\text { погр. 3. (рис. 1, 5) }\end{array}$ & 25 & 9 & 4 & 4 & $\begin{array}{l}\text { раннесарматское } \\
\text { время }\end{array}$ & 2 & [17] \\
\hline 5 & $\begin{array}{l}\text { Калиновка, кург. 6, } \\
\text { погр. } 5 \text { (рис. 1, 4) }\end{array}$ & 26 & 14 & 6,6 & 6 & $\begin{array}{l}\text { среднесарматское } \\
\text { время (І в. н. э. - } \\
\text { первая половина II в. } \\
\text { н. э.) }\end{array}$ & 2 & {$[37$, c. 342$]$} \\
\hline 6 & $\begin{array}{l}\text { Жутово, кург. } 31, \\
\text { погр. } 1 \text { в заполне- } \\
\text { нии (рис. } 2,15)\end{array}$ & - & coxp. 21 & 5,5 & - & $\begin{array}{l}\text { раннесарматское } \\
\text { время }\end{array}$ & 3 & $\begin{array}{l}\quad[16 ; 2, \\
\text { c. } 32-33]\end{array}$ \\
\hline 7 & $\begin{array}{l}\text { Жутово, кург. 34, } \\
\text { погр. 4, } 6 \text { (рис. } 2,1 \text { ) }\end{array}$ & ок. 49,5 & 24 & 4 & 3,1 & $\begin{array}{l}\text { раннесарматское } \\
\text { время (IV в. до н. э.) }\end{array}$ & 2 & $\begin{array}{l}{[17 ; 9,} \\
\text { c. } 67-70]\end{array}$ \\
\hline 8 & $\begin{array}{l}\text { Жутово, кург. } 34, \\
\text { погр. 4, } 6 \text { (рис. } 2,2 \text { ) }\end{array}$ & 48 & 32 & 5,4 & 4 & $\begin{array}{l}\text { раннесарматское } \\
\text { время (IV в. до н. э.) }\end{array}$ & 2 & $\begin{aligned} & {[17 ; 9,} \\
&\text { c. } 67-70]\end{aligned}$ \\
\hline 9 & $\begin{array}{l}\text { Могута, кург. } 8, \\
\text { погр. } 3 \text { (рис. } 2,4 \text { ) }\end{array}$ & 33 & 23 & 6,4 & 3 & $\begin{array}{l}\text { раннесарматское } \\
\text { время }\end{array}$ & 2 & {$[30]$} \\
\hline 10 & $\begin{array}{l}\text { Эльтон, кург. } 10, \\
\text { погр. } 9 \text { (рис. } 2,5 \text { ) }\end{array}$ & 37,6 & 23 & 5,6 & 4,8 & $\begin{array}{l}\text { раннесарматское } \\
\text { время }\end{array}$ & 2 & [13] \\
\hline 11 & $\begin{array}{l}\text { Майеровский III, } \\
\text { кург. 4, погр. 3A } \\
\text { (рис. 2, 6) }\end{array}$ & 30,1 & 19,3 & 4,5 & 3,5 & $\begin{array}{l}\text { раннесарматское } \\
\text { время }\end{array}$ & 2 & $\begin{array}{c}{[28,} \\
\text { c. } 98-117]\end{array}$ \\
\hline 12 & $\begin{array}{l}\text { Ковалевка, кург. 9, } \\
\text { погр. } 1 \text { (рис. } 2,7)\end{array}$ & 36 & 25 & 5,5 & 3 & $\begin{array}{l}\text { раннесарматское } \\
\text { время (II-I вв. до } \\
\text { н. э.) }\end{array}$ & 2 & [8] \\
\hline 13 & $\begin{array}{l}\text { Ковалевка, кург. 11, } \\
\text { погр. } 1 \text { (рис. 2, 12) }\end{array}$ & 25,2 & 16 & 3,1 & 3,2 & $\begin{array}{l}\text { раннесарматское } \\
\text { время (II-I вв. до } \\
\text { н. э.) }\end{array}$ & 2 & [8] \\
\hline 14 & $\begin{array}{l}\text { Ковалевка, кург. 12, } \\
\text { погр. } 2 \text { (рис. } 2,11)\end{array}$ & 33,5 & 16,5 & 4,5 & 3,7 & $\begin{array}{l}\text { раннесарматское } \\
\text { время (II-I вв. до } \\
\text { н. э.) }\end{array}$ & 2 & [8] \\
\hline 15 & $\begin{array}{l}\text { Барановка I, кург. 10, } \\
\text { погр. } 1 \text { (рис. } 2,13 \text { ) }\end{array}$ & coxp. 17,2 & coxp. 10,4 & 3 & 2,6 & $\begin{array}{l}\text { раннесарматское } \\
\text { время }\end{array}$ & 2 & [24] \\
\hline 16 & $\begin{array}{l}\text { Лозной I, гр. III, } \\
\text { кург. 2, погр. } 1 \\
\text { (рис. 2, 14) } \\
\end{array}$ & coxp. 19,4 & 10,4 & 3 & 2,2 & $\begin{array}{l}\text { среднесарматское } \\
\text { время (I в. н. э.) }\end{array}$ & 2 & [33] \\
\hline 17 & $\begin{array}{l}\text { Котлубань V, кург. 2, } \\
\text { погр. } 1 \text { (рис. } 2,10)\end{array}$ & 21 & 11 & 2,4 & 2,8 & $\begin{array}{l}\text { позднесарматское } \\
\text { время }\end{array}$ & 2 & [12] \\
\hline 18 & $\begin{array}{l}\text { Котлубань II, кург. 2, } \\
\text { находка в насыпи } \\
(\text { рис. } 2,9)\end{array}$ & 34 & 20 & 4,2 & 4 & $\begin{array}{l}\text { не определена (cap- } \\
\text { матское время) }\end{array}$ & 2 & [29] \\
\hline 19 & $\begin{array}{l}\text { Солодовка I, кург. } 11 \text {, } \\
\text { погр. } 2 \text { (рис. } 3,1)\end{array}$ & 42 & 28 & 4 & 4,5 & савроматское время & 3 & [6] \\
\hline 20 & $\begin{array}{l}\text { Быково, кург. 2, } \\
\text { погр. } 3 \text { (рис. } 3,3 \text { ) }\end{array}$ & 44 & 29 & 4,8 & 5,4 & $\begin{array}{l}\text { раннесарматское } \\
\text { время (III-II вв. до } \\
\text { н. э.) }\end{array}$ & 3 & [31] \\
\hline
\end{tabular}


В.И. Моисеев, И.А. Будаев. Наконечники копий из погребений савромато-сарматского времени

Окончание таблицы 1

\begin{tabular}{|c|c|c|c|c|c|c|c|c|}
\hline № & Памятник & $\begin{array}{c}\text { Общая } \\
\text { длина, см } \\
\end{array}$ & $\begin{array}{c}\text { Длина } \\
\text { пера, см } \\
\end{array}$ & $\begin{array}{l}\text { Ширина } \\
\text { пера, см }\end{array}$ & $\begin{array}{c}\text { Диаметр } \\
\text { втулки, см } \\
\end{array}$ & Дата комплекса & Тип & Источник \\
\hline \multicolumn{9}{|c|}{ Наконечники копий } \\
\hline 21 & $\begin{array}{l}\text { Калиновка, кург. 28, } \\
\text { погр. } 2 \text { (рис. } 3,12 \text { ) }\end{array}$ & 28,5 & 18,6 & 3 & 4,3 & $\begin{array}{l}\text { позднесарматское } \\
\text { время (II-IV вв. } \\
\text { н. э.) }\end{array}$ & 3 & {$[37$, c. 384$]$} \\
\hline 22 & $\begin{array}{l}\text { Гремячий III, кург. 1, } \\
\text { погр. } 1 \text { (рис. } 3,4 \text { ) }\end{array}$ & 24,6 & 16 & 3 & 5 & $\begin{array}{l}\text { позднесарматское } \\
\text { время (III в. н. э.) }\end{array}$ & 3 & [7] \\
\hline 23 & $\begin{array}{l}\text { Бережновка (юж. } \\
\text { гр.), кург. } 5, \text { погр. } 9 \\
\text { (рис. } 3,6 \text { ) }\end{array}$ & 45 & 23 & 5 & 3 & савроматское время & 4 & {$[27$, c. 114$]$} \\
\hline 24 & $\begin{array}{l}\text { Вертячий, кург. 5, } \\
\text { погр. } 2 \text { (рис. } 3,8)\end{array}$ & 38,8 & 22 & 4 & 3,2 & савроматское время & 4 & [18] \\
\hline 25 & $\begin{array}{l}\text { Журов курган, } \\
\text { погр. } 2 \text { (рис. 3, 7) }\end{array}$ & 38 & 24 & 4,8 & 2,7 & $\begin{array}{l}\text { раннесарматское } \\
\text { время }\end{array}$ & 4 & $\begin{array}{c}{[14,} \\
\text { c. } 160-164] \\
\end{array}$ \\
\hline 26 & $\begin{array}{l}\text { Политотдельское, } \\
\text { кург. } 4, \text { погр.13 } \\
\text { (рис. } 1,6 \text { ) }\end{array}$ & $\begin{array}{c}\text { втулка, } \\
\text { сохр. } \\
\text { часть }-11\end{array}$ & & & 3,5 & сарматское время & - & [11] \\
\hline 27 & $\begin{array}{l}\text { Маляевка } \mathrm{V}, \text { кург. } 3 \text {, } \\
\text { погр. } 3 \text { (рис. } 1,7 \text { ) }\end{array}$ & $\begin{array}{c}\text { втулка, } \\
\text { сохр. } \\
\text { часть }-13\end{array}$ & - & - & 4 & $\begin{array}{l}\text { раннесарматское } \\
\text { время }\end{array}$ & - & [25] \\
\hline 28 & $\begin{array}{l}\text { Солодовка I, кург. } 4 \text {, } \\
\text { погр. } 9 \text { (рис. } 1,9 \text { ) }\end{array}$ & ок. 22 & - & - & 3,5 & $\begin{array}{l}\text { раннесарматское } \\
\text { время (III-II вв. } \\
\text { до н. э.) }\end{array}$ & - & [23] \\
\hline 29 & $\begin{array}{l}\text { Петропавловка I, } \\
\text { кург. } 2 \text {, насыпь-I, } \\
\text { Н-1 (рис. } 1,8 \text { ) }\end{array}$ & - & coxp. 11,5 & 5,9 & - & не определена & - & [21] \\
\hline \multicolumn{9}{|c|}{ Наконечники дротиков } \\
\hline 30 & $\begin{array}{l}\text { Журов курган, } \\
\text { погр. } 2 \text { (рис. } 3,11)\end{array}$ & 30 & 14 & 3,8 & 3 & $\begin{array}{l}\text { раннесарматское } \\
\text { время }\end{array}$ & 4 & $\begin{array}{c}{[14,} \\
\text { c. } 160-164]\end{array}$ \\
\hline 31 & $\begin{array}{l}\text { Журов курган, } \\
\text { погр. } 2 \text { (рис. } 3,10)\end{array}$ & 27 & 5 & 3,4 & 2,5 & $\begin{array}{l}\text { раннесарматское } \\
\text { время }\end{array}$ & 4 & $\begin{array}{c}{[14,} \\
\text { c. } 160-164]\end{array}$ \\
\hline 32 & $\begin{array}{l}\text { Эльтон (гр. у с. При- } \\
\text { озерное), кург. } 2, \\
\text { погр. } 7 \text { (рис. } 3,9 \text { ) }\end{array}$ & 26,5 & 10 & ок. 2,8 & 2,8 & $\begin{array}{l}\text { раннесарматское } \\
\text { время }\end{array}$ & 4 & [15] \\
\hline
\end{tabular}

Таблица 2. Втоки из погребений савромато-сарматского времени с территории Волгоградской области

Table 2. Spear counter-weights from burials of the Savromato-Sarmatian period from the territory of Volgograd region

\begin{tabular}{|c|l|c|c|l|c|}
\hline № & \multicolumn{1}{|c|}{ Памятник } & $\begin{array}{c}\text { Общая } \\
\text { длина, см }\end{array}$ & $\begin{array}{c}\text { Диаметр } \\
\text { втулки, см }\end{array}$ & Дата комплекса & Источник \\
\hline 1 & $\begin{array}{l}\text { Солодовка I, кург. 11, погр. } \\
\text { (рис. 3, 2) }\end{array}$ & 19,4 & 4 & $\begin{array}{l}\text { савроматское } \\
\text { время }\end{array}$ & [6] \\
\hline 2 & $\begin{array}{l}\text { Жутово, кург. 34, погр. 4,6 } \\
\text { (рис. 2, 3) }\end{array}$ & 3,2 & 3,2 & $\begin{array}{l}\text { раннесарматское } \\
\text { время }\end{array}$ & $\begin{array}{l}{[17 ; 9,} \\
\text { с. 67-70] }\end{array}$ \\
\hline 3 & $\begin{array}{l}\text { Гремячий III, кург. 1, погр. 1 } \\
\text { (рис. 3, 5) }\end{array}$ & 14 & 3,6 & $\begin{array}{l}\text { позднесарматское } \\
\text { время (III в. н. э.) }\end{array}$ & {$[7]$} \\
\hline
\end{tabular}




\section{АРХЕОЛОГИЯ ВОСТОЧНО-ЕВРОПЕЙСКИХ СТЕПЕЙ}

\section{СПИСОК ЛИТЕРАТУРЫ}

1. Балабанова, М. А. О преемственности сарматских культур и населения (по материалам Калиновского курганного могильника) / М. А. Балабанова, А. С. Скрипкин // Нижневолжский археологический вестник. - 2018. - Т. 17, № 1. - С. 5-26.

2. Белицкий, А. В. Погребения IV в. до н. э. в бассейне р. Есауловский Аксай / А. В. Белицкий // Исторические, философские, политические и юридические науки, культурология и искусствоведение. Вопросы теории и практики. - Грамота. 2017. - № 12 (86). - Ч. 4. - С. 32-34.

3. Белоусов, В. В. Копья в погребениях сарматов II века до нашей эры - IV века нашей эры на территории Верхнего и Нижнего Подонья / В.В. Белоусов // Нижневолжский археологический вестник. -2010. - Вып. 11. - С. 335-344.

4. Васильев, В. Н. Вооружение и военное дело кочевников Южного Урала в VI-II вв. до н. э. / В. Н. Васильев. - Уфа : Гилем, 2001. - 153 с.

5. Глебов, В. П. Вооружение и военное дело кочевников Нижнего Подонья раннесарматского времени (II-I вв. до н. э.) / В. П. Глебов // Вооружение сарматов: региональная типология и хронология : докл. к VI междунар. конф. «Проблемы сарматской археологии и истории». - Челябинск : Изд-во ЮУрГУ, 2007.- С. 88-98.

6. Глухов, А. А. Отчет о работе археологического отряда «Гюлистан» Волжского гуманитарного института Волгоградского государственного университета в 2002 году. Волжский, 2003 / А. А. Глухов // Архив Волгоградского областного краеведческого музея. - № 188.

7. Демиденко, С. В. Отчет об археологических исследованиях курганного могильника Гремячий III в Котельниковском районе Волгоградской области в 2013. Волгоград, 2015 / С. В. Демиденко // Архив Волгоградского областного краеведческого музея. - № 318 .

8. Дьяченко, А. Н. Отчет о проведении археологических исследований курганного могильника Ковалевка в Октябрьском районе Волгоградской области в 2016 году. Волгоград, 2017 /А.Н.Дьяченко // Архив Волгоградского областного краеведческого музея. - № 338.

9. Клепиков, В. М. Погребения IV в. до н. э. и начало раннесарматской миграции в Нижнем Поволжье / В. М. Клепиков // Археология Волго-Уральского региона в эпоху бронзового, раннего железного веков и средневековья. - Волгоград : Изд-во ВолГУ, 1999. - С. 62-101.

10. Клепиков, В. М. Сарматы Нижнего Поволжья в IV-III вв. до н. э. / В. М. Клепиков. - Волгоград : Изд-во ВолГУ, 2002. - 216с.

11. Комаров, А. М. Отчет о раскопках курганных могильников у с. Политотдельское (Николаевс- кий район), Хохлачевский (Средне-Ахтубинский район), у хутора Молокановский (Октябрьский район), Казачий (Котельниковский район) и одиночного кургана у с. Песковатка (Калачевский район) в зонах строительства оросительных систем в Волгоградской области в 1989 году. Куйбышев, 1990 / А. М. Комаров // Архив Волгоградского областного краеведческого музея. - № 102.

12. Лисицын, И. П. Отчет об археологических работах Городищенского отряда летом 1973 г. / И. П. Лисицын // Архив Волгоградского областного краеведческого музея. - № 124.

13. Лукашов, А. В. Отчет о работе Заволжской археологической экспедиции ВГПИ за 1983 г. / А. В. Лукашов // Архив Волгоградского областного краеведческого музея. - № 122.

14. Лукашов, А. В. Раннесарматский комплекс из Журова кургана / А. В. Лукашов // Древняя история Поволжья. Научные труды. - 1979. T. 230. - C. 160-164.

15. Лукашов, А. В. Отчет о работе археологической экспедиции Волгоградского государственного пединститута под руководством Лукашова А.В. в 1985 году / А. В. Лукашов // Архив Волгоградского областного краеведческого музея. - № 139.

16. Мамонтов, В. И. Отчет о раскопках Жутовского курганного могильника Астраханской экспедицией в 1965 году / В. И. Мамонтов // Архив Волгоградского областного краеведческого музея. - № 21.

17. Мамонтов, В. И. Отчет о работе Приволжского отряда Волго-Донской археологической экспедиции Ленинградского отдела Института археологии АН СССР в Михайловском, Калачевском, Кумыженском районах Волгоградской области в 1972 г. / В. И. Мамонтов // Архив Волгоградского областного краеведческого музея. - № 31 .

18. Мамонтов, В. И. Отчет о работе Приволжского отряда ЛОИА АН СССР, Волгоградского областного отделения ВООПИК и археологического отряда ВГПИ в 1978 г. / В. И. Мамонтов // Архив Волгоградского областного краеведческого музея. - № 37.

19. Мамонтов, В. И. Отчет о работе Приволжского отряда ЛОИА АН СССР, Волгоградской обл. Управления культуры, Обл. отделения ВООПИК и археологического отряда Волгоградского государственного Пединститута в 1981 г. / В. И. Мамонтов // Архив Волгоградского областного краеведческого музея. - № 41 .

20. Мамонтов, В. И. Отчет о работе Приволжского отряда ЛОИА АН СССР и Донской экспедиции НИС ВГПИ в 1983 г. / В. И. Мамонтов // Архив Волгоградского областного краеведческого музея. №43.

21. Мамонтов, В. И. Отчет о работе Приволжского отряда ЛОИА АН СССР в 1988 г. / В. И. Ма- 
монтов // Архив Волгоградского областного краеведческого музея. - № 56.

22. Мелюкова, А. И. Вооружение скифов. Свод археологических источников. Вып. Д1-4 / А. И. Мелюкова. - М. : Наука, 1964. - 92 с. +23 табл.

23. Мыськов, Е. П. Отчет о работе Волго-Ахтубинского отряда археологической экспедиции волгоградского пединститута в 1991 г. / Е. П. Мыськов // Архив Волгоградского областного краеведческого музея. - № 80 .

24. Сергацков, И. В. Отчет об археологических исследованиях Иловлинского отряда археологической экспедиции ВолГУ в Камышенском районе Волгоградской области в 1988 г. / И. В. Сергацков // Архив Волгоградского областного краеведческого музея. - № 59.

25. Сергацков, И. В. Отчет о раскопках курганов близ с. Царев в 1998 г. / И. В. Сергацков // Архив Волгоградского областного краеведческого музея. № 173.

26. Симоненко, А. В. Сарматские всадники Северного Причерноморья / А. В. Симоненко. СПб. : Факультет филологии и искусств СПбГУ : Нестор-История, 2010. - 328 с.

27. Синицын, И. В. Древние памятники в низовьях Еруслана / И. В. Синицын // Материалы и исследования по археологии СССР. - 1960. - № 78, T. 2. - C. 10-168.

28. Скворцов, Н. Б. Погребение сарматской знати из Волгоградского Заволжья / Н. Б. Скворцов, А. С. Скрипкин // Нижневолжский археологический вестник. - 2008. - Вып. 9. - С. 98-117.

29. Скрипкин, А. С. Отчет об археологических разведках и раскопках в зоне строительства Городищенской оросительной системы в 1971 г. / А. С. Скрипкин // Архив Волгоградского областного краеведческого музея. - № 137.

30. Скрипкин, А. С. Отчет об археологических раскопках экспедиции Волгоградского педагогического институга в 1976 г. /А. С. Скрипкин // Архив Волгоградского областного краеведческого музея. - № 85.

31. Скрипкин, А. С. Отчет об археологических раскопках в зоне строительства Большой Волгоградской оросительной системы в Быковском районе Волгоградской области в 1977 г. / А. С. Скрипкин // Архив Волгоградского областного краеведческого музея. - № 86.

32. Скрипкин, А. С. Гибель Скифии. Сарматский фактор / А. С. Скрипкин // Stratum plus. - 2016. № 3. - С. 17-31.

33. Скрипкин, А. Ф. Отчет о работах Донской археологической экспедиции Волгоградского областного краеведческого музея в Чернышевском районе Волгоградской области в 1990 г. / А. Ф. Скрипкин // Архив Волгоградского областного краеведческого музея. - № 118.
34. Смирнов, К. Ф. Вооружение савроматов / К. Ф. Смирнов // Материалы и исследования по археологии СССР. - 1961. - № 101. - 162 с.

35. Соколов, П. М. Савроматская археологическая культура Нижнего Поволжья: проблема хронологии и периодизации : дис. ... канд. ист. наук / Соколов Павел Михайлович. - Махачкала, 2010. $275 \mathrm{c}$.

36. Хазанов, А. М. Очерки военного дела сарматов / А. М. Хазанов. - М. : Наука, 1971. - 171 с.

37. Шилов, В. П. Калиновский курганный могильник / В. П. Шилов // Материалы и исследования по археологии СССР. - 1959. - Т. 1, № 60. - С. 323-523.

\section{REFERENCES}

1. Balabanova M.A., Skripkin A.S. O preemstvennosti sarmatskikh kultur i naseleniya (po materialam Kalinovskogo kurgannogo mogilnika) [On the Succession of Sarmatian Cultures and Population (Based on the Materials of the Kalinovsky Burial Mound)]. Nizhnevolzhskiy arkheologicheskiy vestnik [The Lower Volga Archaeological Bulletin], 2018, vol. 17, no. 1, pp. 5-26.

2. Belitsky A.V. Pogrebeniya IV v. do n. e. v basseyne r. Esaulovskiy Aksay [Burials of the $4^{\text {th }} \mathrm{c}$. BC. in the Basin of the Esaulovsky Aksay River]. Istoricheskie, filosofskie, politicheskie $i$ yuridicheskie nauki, kulturologiya $i$ iskusstvovedenie. Voprosy teorii i praktiki [Historical, Philosophical, Political and Law Sciences, Culturology and Study of Art. Issues of Theory and Practice], 2017, no. 12 (86), part 4, pp. 32-34.

3. Belousov V.V. Kopya $\mathrm{v}$ pogrebeniyakh sarmatov II veka do nashey ery - IV veka nashey ery na territorii Verkhnego i Nizhnego Podonya [Spears in the Burials of Sarmatians of the $2^{\text {nd }}$ Century BC $4^{\text {th }}$ Century AD on the Territory of the Upper and Lower Don]. Nizhnevolzhskiy arkheologicheskiy vestnik [The Lower Volga Archaeological Bulletin], 2010, vol. 11, no. 1, pp. 335-344.

4. Vasilyev V.N. Vooruzhenie $i$ voennoe delo kochevnikov Yuzhnogo Urala v VI-II vv. do n. e. [Armament and Military Affairs of Nomads of the Southern Urals in the $6^{\text {th }}-2^{\text {nd }} c$. BC]. Ufa, Gilem Publ., 2001.153 p.

5. Glebov V.P. Vooruzhenie i voennoe delo kochevnikov Nizhnego Podonya rannesarmatskogo vremeni (II-I vv. do n. e.) [Armament and Military Affairs of Nomads of the Lower Don Region of the Early Sarmatian Time $\left(2^{\text {nd }}-1^{\text {st }} \mathrm{c}\right.$. BC) ]. Vooruzhenie sarmatov: regionalnaya tipologiya i khronologiya : dokl. $k$ VI mezhdunar. konf. "Problemy sarmatskoy arkheologii i istorii» [The Sarmatians Arming: Regional Typology and Chronology. Reports for the 


\section{АРХЕОЛОГИЯ ВОСТОЧНО-ЕВРОПЕЙСКИХ СТЕПЕЙ}

$6^{\text {th }}$ International Conference "The Problems of the Sarmatian Archaeology and History"]. Chelyabinsk, Izd-vo YuUrGU, 2007, pp. 88-98.

6. Glukhov A.A. Otchet o rabote arkheologicheskogo otryada «Gyulistan» Volzhskogo gumanitarnogo instituta Volgogradskogo gosudarstvennogo universiteta $v 2002$ godu. Volzhskiy, 2003 [Report on the Work of "Gulistan" Archaeological Group of Volzhsky Humanitarian Institute of Volgograd State University in 2002. Volzhsky, 2003]. Arkhiv Volgogradskogo oblastnogo kraevedcheskogo muzeya [Archive of Volgograd Regional Museum of Local Lore], no. 188.

7. Demidenko S.V. Otchet ob arkheologicheskikh issledovaniyakh kurgannogo mogilnika Gremyachiy III v Kotelnikovskom rayone Volgogradskoy oblasti v 2013. Volgograd, 2015 [Report on Archaeological Research of Gremyachiy III Burial Ground in Kotelnikovsky District of Volgograd Region in 2013. Volgograd, 2015]. Arkhiv Volgogradskogo oblastnogo kraevedcheskogo muzeya [Archive of Volgograd Regional Museum of Local Lore], no. 318.

8. Dyachenko A.N. Otchet o provedenii arkheologicheskih issledovaniy kurgannogo mogilnika Kovalevka v Oktyabrskom rayone Volgogradskoy oblasti v 2016 godu. Volgograd, 2017 [Report on the Archaeological Research of Kovalevka Burial Mound in Oktyabrsky District of Volgograd Region in 2016. Volgograd, 2017]. Arkhiv Volgogradskogo oblastnogo kraevedcheskogo muzeya [Archive of Volgograd Regional Museum of Local Lore], no. 338.

9. Klepikov V.M. Pogrebeniya IV v. do n. e. i nachalo rannesarmatskoy migratsii $\mathrm{v}$ Nizhnem Povolzhye [Burials of the $4^{\text {th }} \mathrm{c}$. BC and the Beginning of the Early Sarmatian Migration in the Lower Volga Region]. Arkheologiya Volgo-Uralskogo regiona $v$ epokhu bronzovogo, rannego zheleznogo vekov $i$ srednevekovya [Archaeology of the Volga-Ural Region in the Bronze, Early Iron Ages and the Middle Ages]. Volgograd, Izd-vo VolGU, 1999, pp. 62-101.

10. Klepikov V.M. Sarmaty Nizhnego Povolzhy a IV-III vv. do n. e. [Sarmatians of the Lower Volga Region in the $4^{\text {th }}-3^{\text {rd }} c$. BC]. Volgograd, Izd-vo VolGU, 2002. 216p.

11. Komarov A.M. Otchet o raskopkakh kurgannykh mogilnikov u s. Politotdelskoe (Nikolaevskiy rayon), Khokhlachevskiy (SredneAkhtubinskiy rayon), u khutora Molokanovskiy (Oktyabrskiy rayon), Kazachiy (Kotelnikovskiy rayon) i odinochnogo kurgana u s. Peskovatka (Kalachevskiy rayon) v zonakh stroitelstva orositelnykh sistem $\mathrm{v}$ Volgogradskoy oblasti v 1989 godu. Kuybyshev, 1990 [Report on the Excavations of Burial Mounds Near Politotdelskoe Settlement (Nikolaevskiy District), Khokhlachevsky (Sredne-Akhtubinskiy District), near Molchanovskiy Khutor (Oktyabrskiy District),
Kazachiy (Kotelnikovskiy District) and a Single Mound near Peskovatka Settlement (Kalachevskiy District) in the Areas of Irrigation System Construction in Volgograd Region in 1989. Kuybyshev, 1990]. Arkhiv Volgogradskogo oblastnogo kraevedcheskogo muzeya [Archive of Volgograd Regional Museum of Local Lore], no. 102.

12. Lisitsyn I.P. Otchet ob arkheologicheskikh rabotakh Gorodishchenskogo otryada letom $1973 \mathrm{~g}$. [Report on Archaeological Work of the Gorodishche Squad in Summer 1973]. Arkhiv Volgogradskogo oblastnogo kraevedcheskogo muzeya [Archive of Volgograd Regional Museum of Local Lore], no. 124.

13. Lukashov A.V. Otchet o rabote Zavolzhskoy arkheologicheskoy ekspeditsii VGPI za 1983 g. [Report on the Work of the Volga Archaeological Expedition of VSPI for 1983]. Arkhiv Volgogradskogo oblastnogo kraevedcheskogo muzeya [Archive of Volgograd Regional Museum of Local Lore], no. 122.

14. Lukashov A.V. Rannesarmatskiy kompleks iz Zhurova kurgana [Early Sarmatian Complex of Zhurov Mound]. Drevnyaya istoriya Povolzhya. Nauchnye trudy, 1979, vol. 230, pp. 160-164.

15. Lukashov A.V. Otchet o rabote arkheologicheskoy ekspeditsii Volgogradskogo gosudarstvennogo pedinstituta pod rukovodstvom Lukashova A.V. v 1985 godu [Report on the Work of the Archaeological Expedition of Volgograd State Pedagogical Institute Under the Leadership of Lukashov A.V. in 1985]. Arkhiv Volgogradskogo oblastnogo kraevedcheskogo muzeya [Archive of Volgograd Regional Museum of Local Lore], no. 139.

16. Mamontov V.I. Otchet o raskopkakh Zhutovskogo kurgannogo mogilnika Astrakhanskoy ekspeditsiey v 1965 godu [Report on Excavations of Zhutovskiy Burial Mound by Astrakhan Expedition in 1965]. Arkhiv Volgogradskogo oblastnogo kraevedcheskogo muzeya [Archive of Volgograd Regional Museum of Local Lore], no. 21.

17. Mamontov V.I. Otchet o rabote Privolzhskogo otryada Volgo-Donskoy arkheologicheskoy ekspeditsii Leningradskogo otdela Instituta arkheologii AN SSSR v Mikhaylovskom, Kalachevskom, Kumyzhenskom rayonakh Volgogradskoy oblasti v 1972 g. [Report on the Work of the Squad of the Volga-Don Archaeological Expedition of the Leningrad Division of Archaeology Institute of the USSR Academy of Sciences in Mikhailovskiy, Kalachevskiy, Kumyzhenskiy Districts of Volgograd Region in 1972]. Arkhiv Volgogradskogo oblastnogo kraevedcheskogo muzeya [Archive of Volgograd Regional Museum of Local Lore], no. 31.

18. Mamontov V.I. Otchet o rabote Privolzhskogo otryada LOIA AN SSSR, Volgogradskogo oblastnogo otdeleniya VOOPIK i arkheologicheskogo otryada VGPI v $1978 \mathrm{~g}$. [Report on the Work of the Volga Squad of the Leningrad Branch 
of Institute of Archaeology of the USSR Academy of Sciences, Volgograd Regional Branch of the AllRussian Society for the Protection of Historical and Cultural Monuments and the Archaeological Squad of Volgograd State Pedagogical Institute in 1978]. Arkhiv Volgogradskogo oblastnogo kraevedcheskogo muzeya [Archive of Volgograd Regional Museum of Local Lore], no. 37.

19. Mamontov V.I. Otchet o rabote Privolzhskogo otryada LOIAAN SSSR, Volgogradskoy obl. Upravleniya kultury, Obl. otdeleniya VOOPIK i arkheologicheskogo otryada Volgogradskogo gosudarstvennogo Pedinstituta v 1981 g. [Report on the Work of the Volga Squad of the Leningrad Branch of Institute of Archaeology of the USSR Academy of Sciences, Volgograd Regional Department of Culture, Volgograd Regional Branch of the All-Russian Society for the Protection of Historical and Cultural Monuments and Archaeological Squad of Volgograd State Pedagogical Institute in 1981]. Arkhiv Volgogradskogo oblastnogo kraevedcheskogo muzeya [Archive of Volgograd Regional Museum of Local Lore], no. 41.

20. Mamontov V.I. Otchet o rabote Privolzhskogo otryada LOIA AN SSSR i Donskoy ekspeditsii NIS VGPI v 1983 g. [Report on the Work of the Volga Squad of the Leningrad Branch of Institute of Archaeology of the USSR Academy of Sciences and the Don Expedition of the Volgograd State Pedagogical Institute Research Sector in 1983]. Arkhiv Volgogradskogo oblastnogo kraevedcheskogo muzeya [Archive of Volgograd Regional Museum of Local Lore], no. 43.

21. Mamontov V.I. Otchet o rabote Privolzhskogo otryada LOIA AN SSSR v 1988 g. [Report on the Work of the Volga Squad of the Leningrad Branch of Institute of Archaeology of the USSR Academy of Sciences in 1988]. Arkhiv Volgogradskogo oblastnogo kraevedcheskogo muzeya [Archive of Volgograd Regional Museum of Local Lore], no. 56.

22. Melyukova A.I. Vooruzhenie skifov. Svod arkheologicheskikh istochnikov [Weapons of the Scythians. Code of Archaeological Sources]. Moscow, Nauka Publ., 1964, iss. Д1-4. 92 p. + 23 tables.

23. Myskov E.P. Otchet o rabote VolgoAkhtubinskogo otryada arkheologicheskoy ekspeditsii volgogradskogo pedinstituta v $1991 \mathrm{~g}$. [Report on the Work of the Volga-Akhtuba Squad of the Archaeological Expedition of Volgograd Pedagogical Institute in 1991]. Arkhiv Volgogradskogo oblastnogo kraevedcheskogo muzeya [Archive of Volgograd Regional Museum of Local Lore], no. 80.

24. Sergatskov I.V. Otchet ob arkheologicheskikh issledovaniyakh Ilovlinskogo otryada arkheologicheskoy ekspeditsii VolGUv Kamyshenskom rayone Volgogradskoy oblasti v 1988 g. [Report on the Archaeological Research of Ilovlinskiy Squod of the Archaeological Expedition of VolSU in Kamyshenskiy District of Volgograd Region in 1988]. Arkhiv Volgogradskogo oblastnogo kraevedcheskogo muzeya [Archive of Volgograd Regional Museum of Local Lore], no. 59.

25. Sergatskov I.V. Otchet o raskopkakh kurganov bliz s. Tsarev v 1998 g. [Report on the Excavations of Barrows near Tsarev Settlement in 1998]. Arkhiv Volgogradskogo oblastnogo kraevedcheskogo muzeya [Archive of Volgograd Regional Museum of Local Lore], no. 173.

26. Simonenko A.V. Sarmatskie vsadniki Severnogo Prichernomorya [Sarmatian Riders of the North Pontic Region]. Saint Petersburg, Fakultet filologii i iskusstv SPbGU, Nestor-Istoriya Publ., 2009. $328 \mathrm{p}$.

27. Sinitsyn I.V. Drevnie pamyatniki v nizovyakh Eruslana [Ancient Monuments in the Lower Reaches of Eruslan]. Materialy i issledovaniya po arkheologii SSSR, 1960, no. 78, vol. 2, pp. 10-168.

28. Skvortsov N.B., Skripkin A.S. Pogrebenie sarmatskoy znati iz Volgogradskogo Zavolzhya [Burial of the Sarmatian Nobility from Trans-Volga Region]. Nizhnevolzhskiy arkheologicheskiy vestnik [The Lower Volga Archaeological Bulletin], 2008, iss. 9, pp. 98-117.

29. Skripkin A.S. Otchet ob arkheologicheskikh razvedkakh i raskopkakh $\mathrm{v}$ zone stroitelstva Gorodishchenskoy orositelnoy sistemy v 1971 g. [Report on Archaeological Surveys and Excavations in the Construction Zone of the Gorodishche Irrigation System in 1971]. Arkhiv Volgogradskogo oblastnogo kraevedcheskogo muzeya [Archive of Volgograd Regional Museum of Local Lore], no. 137.

30. Skripkin A.S. Otchet ob arkheologicheskikh raskopkakh ekspeditsii Volgogradskogo pedagogicheskogo instituta v 1976 g. [Report on Archaeological Excavations of the Expedition of Volgograd Pedagogical Institute in 1976]. Arkhiv Volgogradskogo oblastnogo kraevedcheskogo muzeya [Archive of Volgograd Regional Museum of Local Lore], no. 85.

31. Skripkin A.S. Otchet ob arkheologicheskikh raskopkakh v zone stroitelstva Bolshoy Volgogradskoy orositelnoy sistemy v Bykovskom rayone Volgogradskoy oblasti v 1977 g. [Report on Archaeological Excavations in the Construction Zone of the Great Volgograd Irrigation System in Bykovskiy District of Volgograd Region in 1977]. Arkhiv Volgogradskogo oblastnogo kraevedcheskogo muzeya [Archive of Volgograd Regional Museum of Local Lore], no. 86.

32. Skripkin A.S. Gibel Skifii. Sarmatskiy faktor [The Fall of Scythia. The Sarmatian Faktor]. Stratum plus, 2016, no. 3, pp. 17-31. 


\section{АРХЕОЛОГИЯ ВОСТОЧНО-ЕВРОПЕЙСКИХ СТЕПЕЙ}

33. Skripkin A.F. Otchet o rabotakh Donskoy arkheologicheskoy ekspeditsii Volgogradskogo oblastnogo kraevedcheskogo muzeya $\mathrm{V}$ Chernyshevskom rayone Volgogradskoy oblasti v 1990 g. [Report on the Works of the Don Archaeological Expedition of the Volgograd Regional Museum of Local Lore in Chernyshevsky District of Volgograd Region in 1990]. Arkhiv Volgogradskogo oblastnogo kraevedcheskogo muzeya [Archive of Volgograd Regional Museum of Local Lore], no. 118.

34. Smirnov K.F. Vooruzhenie savromatov [Armament of Savromats]. Materialy i issledovaniya po arkheologii SSSR, 1961, no. $101.162 \mathrm{p}$.
35. Sokolov

P.M.

Savromatskaya arkheologicheskaya kultura Nizhnego Povolzhya: problema khronologii i periodizatsii : dis. ... kand. ist. nauk [Savromatian Archaeological Culture of the Lower Volga Region: The Problem of Chronology and Periodization. Cand. hist. sci. diss.]. Makhachkala, 2010.275 p.

36. Khazanov A.M. Ocherki voennogo dela sarmatov [Essays on the Military Affairs of Sarmatians]. Moscow, Nauka Publ., 1971. 171 p.

37. Shilov V.P. Kalinovskiy kurgannyy mogilnik [Kalinovskiy Burial Ground]. Materialy $i$ issledovaniya po arkheologii SSSR, 1959, vol. 1, no. 60 , pp. $323-523$.

\section{Information about the Authors}

Vladimir I. Moiseev, Researcher, Laboratory of Archaeological Research, Volgograd State University, Prosp. Universitetsky, 100, 400062 Volgograd, Russian Federation, v.moiseev@volsu.ru, https://orcid.org/0000-0002-5110-733X

Igor A. Budaev, Specialist, Laboratory of Archaeological Research, Volgograd State University, Prosp. Universitetsky, 100, 400062 Volgograd, Russian Federation, iabudaev@volsu.ru, https://orcid.org/0000-0002-8282-8412

\section{Информация об авторах}

Владимир Иванович Моисеев, научный сотрудник лаборатории археологических исследований, Волгоградский государственный университет, просп. Университетский, 100, 400062 г. Волгоград, Российская Федерация, v.moiseev@volsu.ru, https://orcid.org/0000-0002-5110-733X

Игорь Александрович Будаев, специалист лаборатории археологических исследований, Волгоградский государственный университет, просп. Университетский, 100, 400062 г. Волгоград, Российская Федерация, iabudaev@volsu.ru, https://orcid.org/0000-0002-8282-8412 